\title{
Hydrogeological Properties of the Rocks in Adansi Mining Area, Ghana*
}

\author{
A. Asante-Annor and A. Ewusi
}

Asante-Annor, A. and Ewusi, A. (2016), "Hydrogeological Properties of the Rocks in Adansi Mining Area Ghana”, Ghana Mining Journal, Vol. 16, No. 1, pp. 31 - 39.

\begin{abstract}
Groundwater is an important resource in the Adansi mining area as some communities in the area are not connected to the Ghana national water network. These communities therefore utilise groundwater for potable water supply. The hydrogeological properties of an aquifer coupled with climatic conditions and geomorphology determines how much groundwater exists in that location. A hydrogeological study of the rocks in the Adansi area was carried out to obtain the aquifer hydraulic properties. Drilling and pumping test analysis information were used to assess these properties. The average borehole depth in the area was $44.3 \mathrm{~m}$ whilst the average static water level is $10.75 \mathrm{~m}$. There is a general decrease in yield with an increase in borehole total depth. There is also no strong correlation between aquifer saturated thickness, yield and drawdown. Transmissivity of the aquifer decreases from the phyllite, argillitc sediments, granites to sandstone. Three hydrogeological regimes (> $0.9 \mathrm{~m} /$ day, $0.9-0.09 \mathrm{~m} /$ day and $<0.09 \mathrm{~m} /$ day) were also realised based on the hydraulic conductivity. The spatial distribution of the hydraulic properties suggests the influence of geological structures on the occurrence of groundwater in the area.
\end{abstract}

Keywords: Hydrogeological Properties, Mining, Hydraulic, Drilling, Groundwater

\section{Introduction}

In the Adansi area of Ghana, groundwater resource is very important for potable water supply because most of the surface water resources have been polluted as a result of small scale mining activities. Most of these communities are also not connected to piped water systems from the Ghana Water Company Limited (GWCL). The demand for water resources varies considerably from urban centres; where water is used mainly for domestic and industrial purposes; to remote villages where water is mainly used for domestic, agricultural and mining purposes. In view of its accessibility in remote areas, groundwater is becoming a useful alternative water source in rural communities as well as some urban areas in Ghana (Martin and van de Giesen, 2005).

In spite of the importance of groundwater as a major source of potable water in many rural communities in Ghana, its predictability and availability is difficult, particularly in the areas underlain by crystalline rocks. This is perhaps attributable to the heterogeneous nature of the water bearing materials developed in the weathered zones and in fractures of the bedrocks, as well as lack of detailed and sufficient hydrogeological information to properly characterize and delineate the aquifers accordingly. Thus, a better insight of the hydrogeological parameters will contribute to a better characterisation of these aquifers for water supply. Previous work done elsewhere on hydrogeological parameters by Hölting and Coldewey (2009) enabled water bearing rocks to be classified, on a basis of hydraulic conductivity $\mathrm{K}$, into aquifer, aquiclude, and aquitard (Table 1).

The main aim of this study therefore, is to determine the hydrogeological properties of the crystalline basement rocks in the Adansi area. The rational is that the findings will add to the understanding of the general hydrogeological parameters in the area to enable detailed aquifer characterisation to be carried out.

Table 1 Characterisation of Hydrogeological Condition using K (Hölting and Coldewey, 2009)

\begin{tabular}{|c|c|c|c|c|}
\hline $\begin{array}{c}\mathbf{K} \\
(\mathbf{m} / \mathbf{s})\end{array}$ & $\begin{array}{c}\mathbf{K} \\
(\mathbf{m} / \mathbf{d a y})\end{array}$ & Hydrogeological condition & Permeability & Water bearing capacity \\
\hline$>10^{-5}$ & $>0.9$ & Aquifer & Very high & Good - very Good \\
\hline $10^{-5}-10^{-7}$ & $0.9-0.01$ & Aquiclude & Relatively low & Small - Medium \\
\hline$<10^{-7}$ & $<0.01$ & Aquitards & Impermeable & Very small \\
\hline
\end{tabular}

*Manuscript received September 30, 2015 


\subsection{The Study Area}

The Adansi study area (Fig. 1) is located within the Adansi South and Adansi North Districts of the Ashanti Region of Ghana. The area lies between longitudes $1^{\circ} 06^{\prime} \mathrm{W}$ and $1^{\circ} 38^{\prime} \mathrm{W}$ and latitude $6^{\circ} 00^{\prime}$ $\mathrm{N}$ and $6^{\circ} 20^{\prime} \mathrm{N}$. The land is flat to gentle undulating with average elevation of about 350 metres above sea level. Generally, the district is hilly with several streams and major rivers such as Pra, Fosu, Muma and Subin. The district experiences semiequatorial climatic conditions with mean monthly temperatures ranging between $26{ }^{\circ} \mathrm{C}$ and $30{ }^{\circ} \mathrm{C}$. The mean annual temperature is $27{ }^{\circ} \mathrm{C}$ whilst February and March are the hottest periods in the year. The annual total rainfall is between $1250 \mathrm{~mm}$ and $1800 \mathrm{~mm}$. A double maxima rainfall regime is experienced in the district. The major rains occur between April and July whilst the minor rains occur between September and December. Relative humidity is about $80 \%$ in the rainy season and 20 $\%$ in the dry season. The temperature and rainfall pattern enhance the cultivation of food and cash crops such as cocoa, oil palm, citrus, vegetables, yam, cassava and cocoyam.

\subsection{Geology}

The Adansi area falls within the Ashanti greenstone belt of the Western Region of Ghana. The Belt is made up of paleoproterozoic, metavolcanic and metasedimentary rocks. The rocks are divided into the Birimian Supergroup and the Tarkwaian Group with associated granitoid intrusions (Fig. 2).

Major thrust faults occur within the units which include the Ashanti fault. Regional scale open folds occur in the Tarkwaian sediments and isoclinal folds in the Birimian metasedimentary rocks. These features are modified by different phases of deformational events resulting in shear zones with strong shear fabrics (Perrouty et al., 2012). The Birimian and Tarkwaian rock units generally store a considerable amount of water which may flow through the joints, fractures, foliation and bedding patterns (Kesse, 1985). Metamorphism is widespread with the exception of some late Eburnean granitoid dykes and Phanerozoic sediments. The metamorphism does not exceed upper greenschist facies (Oldcorn et al., 2013).

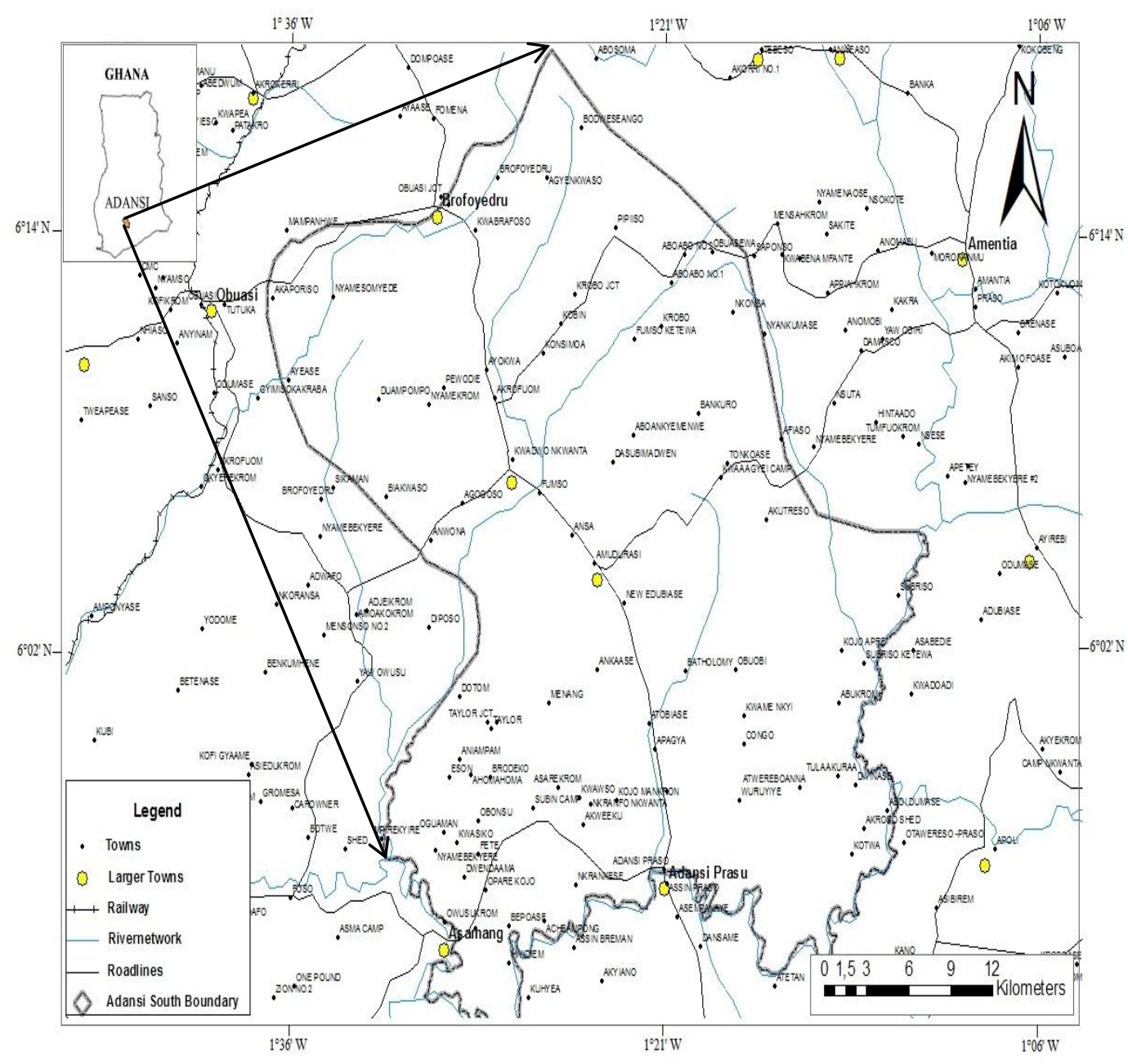

Fig. 1 Adansi Area and Borehole Sample Points 


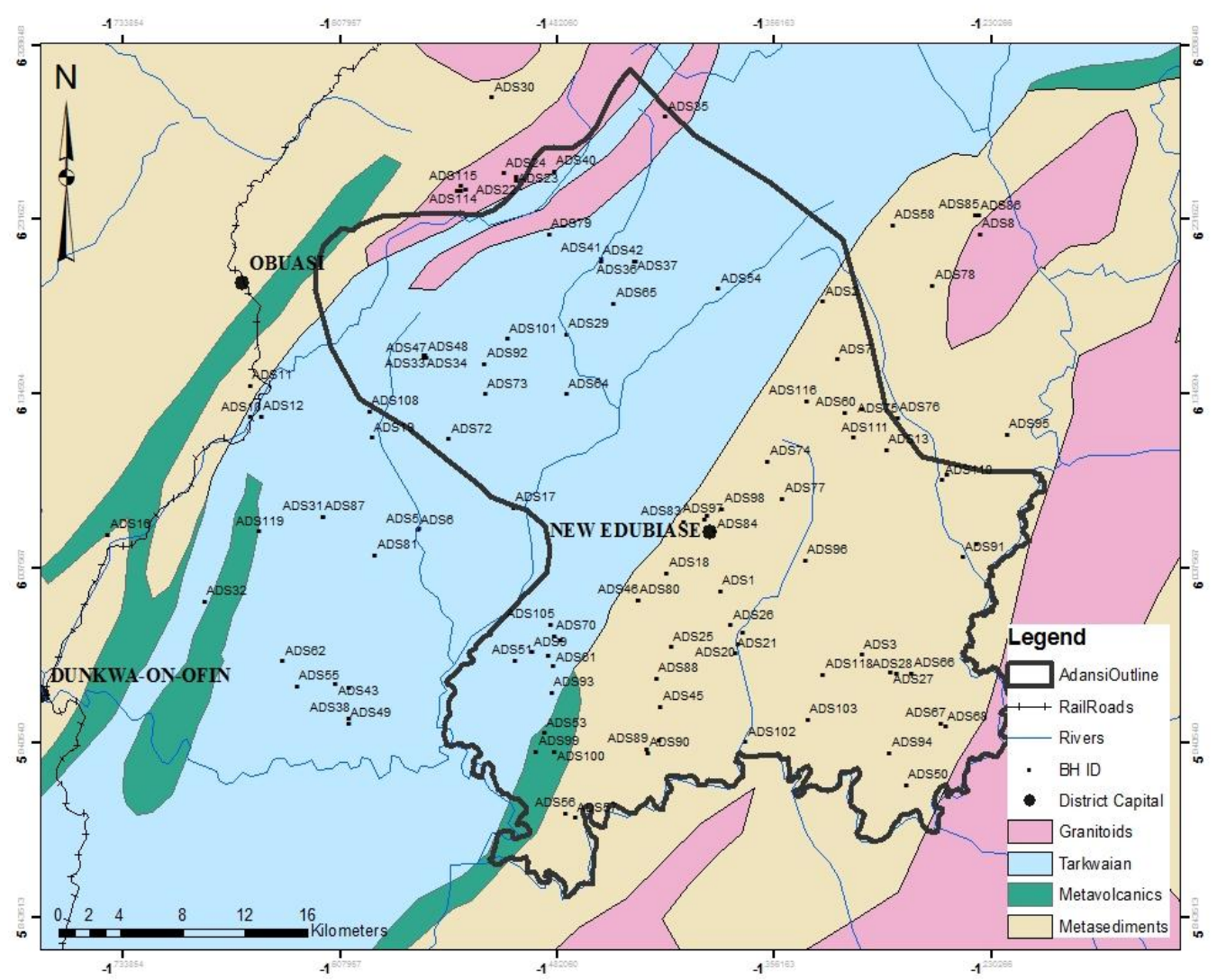

Fig. 2 Geological Map of Adansi Area

\section{Resources and Methods Used}

A total of 111 borehole data were used as data sources. Borehole logs reports and information such as type of rock material, thickness of saturated zones, presence of geological structures (fractures, joints and bedding plane), soil profile, average yield, drilling type and rate were acquired from AYA Consult Ltd. Results from the pumping test analysis were used to determine the single well aquifer transmissivity which was also used to determine the hydraulic conductivity knowing the saturated thickness. The maximum discharge and drawdown of the wells were used to calculate the specific capacity.

\subsection{Drilling Information}

Information on the rock type, fractures, vadose and saturated zones, and confining rock materials were determined from drill cuttings. After completion of successful boreholes, static water levels (SWL) were measured. Dry boreholes were backfilled and sealed with grouts whilst successful boreholes were cased and screened at water bearing zones for further development.

Locally, the rock types occurring in the Adansi area were of five major types belonging to the Birimian Supergroup, Tarkwaian Group and the Eburnean Plutonic Suite. They were argillitic sediments (AS), phyllites (P), sandstone (SS), granites $(\mathrm{G})$, and the quartz veins (LQ). Phyllites dominated the study area (Fig. 2) with 63 boreholes representing $57 \%$ of the total boreholes in the study area (Fig. 3). The argillitic sediments, sandstones, granites and quartz vein had $32 \%, 6 \%, 4 \%$ and $1 \%$ of the total boreholes respectively.

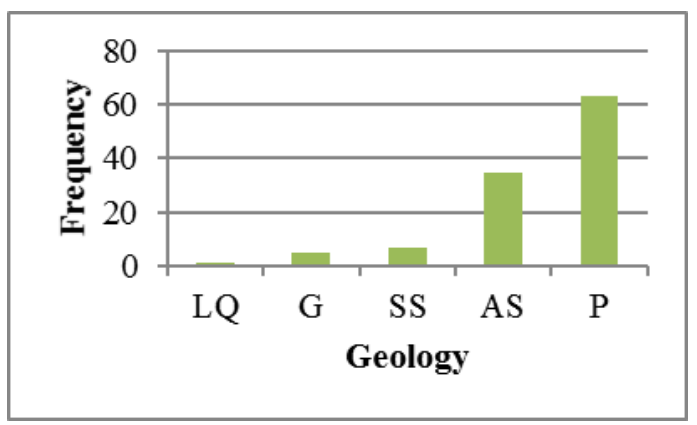

Fig. 3 Frequency distribution of Geology from drilling records

\subsection{Pumping Test Analysis}

The tests were conducted over a period of 9 hours for all the boreholes for two stages. The first stage was the pumping stage in which water was pumped out of the borehole for 6 hours at a constant rate after which the second stage of recovery of 3 hours followed. During the pumping and the recovery stages, water level measurements were recorded. 
The time-drawdown data for the single pumping wells were analysed using the Cooper-Jacob method (Cooper \& Jacob, 1946). It is commonly referred to as the Cooper-Jacob straight-line approximation method (Freeze \& Cherry, 1979) and is a simplification of the Theis solution (Theis, 1935) for flow to a fully penetrating wells in a confined aquifer. The following assumptions apply to the analytical solution:

(i) Aquifer has infinite extent, and is homogeneous, and isotropic.

(ii) Well discharge is at a constant rate.

(iii) Well fully penetrates the confined aquifer resulting in horizontal flow to the well and flow is laminar.

(iv) Aquifer has uniform thickness and is horizontal.

(v) The potentiometric surface is horizontal initially

(vi) Aquifer is fully confined and discharge is derived exclusively from storage.

The equation for predicting drawdown (s) at the well is as follows:

$$
\mathrm{S}=\frac{\mathrm{Q}}{4 \pi \mathrm{T}} \ln \frac{2.25 \mathrm{Tt}}{\mathrm{r}_{\mathrm{w}}^{2} \mathrm{~s}}
$$

where,

$\mathrm{T}=$ aquifer transmissivity (L2/T),

$\mathrm{Q}=$ constant discharge rate $(\mathrm{L} 3 / \mathrm{T})$,

$\mathrm{s}=$ storage coefficient $(\mathrm{L} / \mathrm{L})$,

$\mathrm{S}=$ drawdown $(\mathrm{L})$,

$\mathrm{t}=$ time $(\mathrm{T})$, and

$\mathrm{r}_{\mathrm{w}}=$ the well radius $(\mathrm{L})$.

\subsection{Estimation of Transmissivity}

For the Cooper-Jacob straight-line method, drawdown is plotted with an arithmetic scale on the $y$-axis versus time plotted with a logarithmic scale on the $\mathrm{X}$-axis. Transmissivity (T) is estimated from the pumping rate $(\mathrm{Q})$ and the change in drawdown per one log-cycle $(\Delta s)$ from the following equation:

$$
\mathrm{T}=\frac{2.3 \mathrm{Q}}{4 \pi \Delta \mathrm{s}}
$$

where,

$\Delta \mathrm{s}=$ change in drawdown per log-cycle (L).

$\pi=$ constant $(3.142)$

The Cooper and Jacob method is based on linear curve fitting; it can be applied with a higher level of accuracy, and was therefore preferred for the evaluation of drawdown data. The pumping test data was analysed using a spreadsheet developed by Keith J. Halford and Eve L. Kuniansky for the USGS (Halford \& Kuniansky, 2002). The aquifer- test spreadsheets are based on drawdown response to a pumping well or a flowing well.

After estimating the transmissivity, the hydraulic conductivity $\mathrm{K}$ was calculated using the following equation:

$$
\mathrm{T}=\mathrm{Kb}
$$

where $\mathrm{T}$ is transmissivity, $\mathrm{K}$ is hydraulic conductivity and $\mathrm{b}$ is the aquifer thickness.

\subsection{Determination of Specific Capacity}

Knowing the pumping rate $\mathrm{Q}$ and the drawdown $\mathrm{S}$, the specific capacity which is a measure of available groundwater is calculated by the relation:

$$
\text { Specific capacity }=\frac{\text { Discharge }(\mathrm{Q})}{\text { Drawdown }(\mathrm{S})}
$$

\subsection{Spatial Distribution of Hydraulic Properties}

Statistical tools and ArcGIS were used to analyse the acquired data and the spatial distribution of the hydraulic parameters respectively. The ArcGIS was used to determine the spatial extent of the hydraulic properties. The method of interpolation was used to display point shape files of hydraulic conductivity, drawdown, weathering activity and specific capacity for all borehole locations. The Inverse Distance Weighted (IDW) method of interpolation that estimates cell values by averaging the values of sample data points in the neighbourhood of each processing cell (Anon., 2009) was applied. The closer a point is to the centre of the estimated cell, the more influence, or weight it has in the averaging process. This method was chosen over other methods as hydraulic conductivity and other structural controlled activity in the area tends to be unequally distributed; it increases in areas of high tectonic activity and decreases in areas where the rock is relatively fresh. The interpolation tool was assessed using the ArcGIS Spatial Analyst toolbar in ArcMap. Colour ramp was used to distinguish the various groups of the hydrogeologic parameters.

\section{Results and Discussion}

\subsection{Hydraulic properties}

A summary of the results of the hydraulic properties of the aquifers in the Adansi area are presented in Table 2. The average borehole depth for the study area was $44.3 \mathrm{~m}$ ranging from $29 \mathrm{~m}$ to $67 \mathrm{~m}$. Boreholes in the sandstone had the highest mean of $50 \mathrm{~m}$ whilst the lowest occurred in the Argillitic sediments at $40 \mathrm{~m}$. 
Table 2 Summary of Hydraulic Properties of Aquifers

\begin{tabular}{|c|c|c|c|c|c|c|c|c|c|}
\hline Geology & Statistics & $\begin{array}{c}\text { Depth } \\
\text { (m) }\end{array}$ & $\begin{array}{c}\text { SWL } \\
(\mathrm{m})\end{array}$ & $\begin{array}{c}\text { Thickness } \\
\text { (m) }\end{array}$ & $\begin{array}{c}Q \\
\mathrm{~m}^{3} / \mathrm{day}\end{array}$ & $\begin{array}{c}\mathrm{T} \\
\left(\mathrm{m}^{2} / \mathrm{day}\right)\end{array}$ & $\begin{array}{c}\mathbf{K} \\
(\mathbf{m} / \text { day })\end{array}$ & $\begin{array}{c}\mathbf{S} \\
(\mathbf{m})\end{array}$ & $\begin{array}{c}\text { Q/S } \\
\mathrm{m}^{3} / \mathrm{day} / \mathrm{m}\end{array}$ \\
\hline \multirow{3}{*}{$\begin{array}{l}\text { Argillitic } \\
\text { Sediment }\end{array}$} & Range & $30-55$ & $2-21$ & $7-19$ & 14-259 & $0.5-43.7$ & $0.05-3.36$ & $6-27$ & $0.8-43.2$ \\
\hline & Mean & 40 & 11 & 11 & 68 & 7.1 & 0.66 & 13 & 6.2 \\
\hline & STD & 6 & 6 & 2 & 59 & 9.5 & 0.84 & 4 & 7.8 \\
\hline \multirow{3}{*}{ Granite } & Range & $36-53$ & $3-10$ & $10-19$ & 19-173 & $0.4-10.8$ & $0.02-0.74$ & $8-25$ & $0.8-13.7$ \\
\hline & Mean & 43 & 7 & 15 & 83 & 4.6 & 0.35 & 15 & 6.9 \\
\hline & STD & 8 & 3 & 3 & 69 & 4,4 & 0.36 & 7 & 5.6 \\
\hline Lose Quartz & Range & 41 & 12 & 10 & 17 & 0.3 & 0.03 & 16 & 1.1 \\
\hline \multirow{3}{*}{ Phyllite } & Range & $29-67$ & $1-27$ & $7.0-18.0$ & $14-259$ & $0.3-59.3$ & $0.02-4.56$ & $6-24$ & $0.6-43.2$ \\
\hline & Mean & 44 & 11 & 12.4 & 63 & 6.1 & 0.51 & 12 & 6.6 \\
\hline & STD & 7 & 6 & 2,6 & 61 & 9.1 & 0.73 & 4 & 8.7 \\
\hline \multirow{3}{*}{ Sandstone } & Range & $36-61$ & $2-23$ & $12-18$ & $16-46$ & $0.6-6.5$ & $0.03-0.43$ & $8-17$ & $0.9-4.0$ \\
\hline & Mean & 50 & 14 & 14.9 & 29 & 2.7 & 0.19 & 11 & 2.8 \\
\hline & STD & 11 & 7 & 2.0 & 11 & 2,0 & 0.14 & 3 & 1.1 \\
\hline Study area & Average & 44.25 & 10.75 & 13.325 & 60.75 & 5.125 & 0.4275 & 12.75 & 5.625 \\
\hline
\end{tabular}

Average static water level was $10.8 \mathrm{~m}$ ranging from $1 \mathrm{~m}$ to $27 \mathrm{~m}$ with the highest and the lowest mean occurring within the Sandstones $(14 \mathrm{~m})$ and the phyllites $(1 \mathrm{~m})$ respectively. A comparison of total borehole depth with static water level (SWL) (Fig. 4A) shows an increase in the depth with the SWL (gradient of 0.4). There is a general decline in the yield with increasing borehole total depth (Fig. 4B) with an average gradient of - 0.1 (granite - 0.3 , phyllite -0.1 , argillite and sandstone - 0.03).

Average aquifer thickness was $13.3 \mathrm{~m}$ ranging from 7 to $19 \mathrm{~m}$ with the highest average saturated

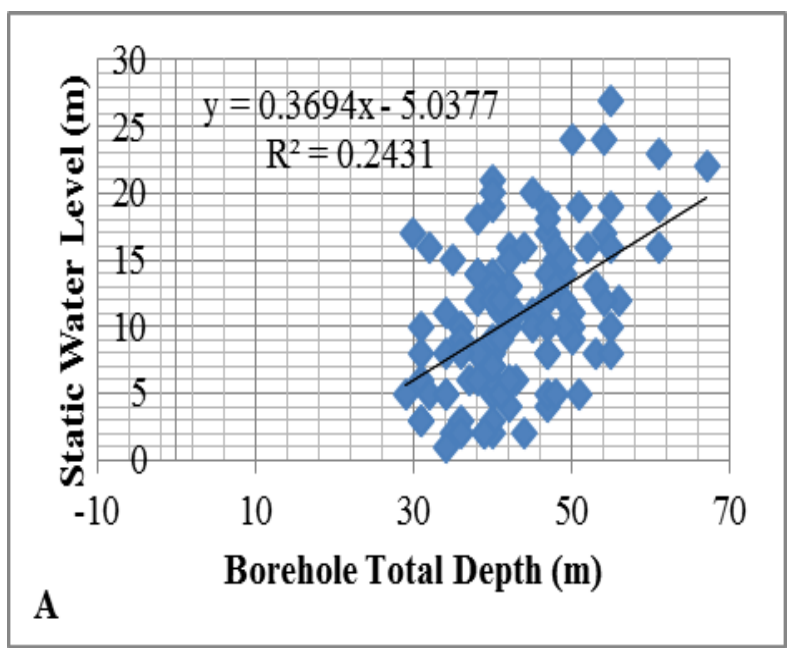

zone occurring within the granites and sandstones $(15 \mathrm{~m})$. The yield $\mathrm{Q}$ averaged $61 \mathrm{~m}^{3} /$ day ranging from 11 to $259 \mathrm{~m}^{3} /$ day with the highest yield 259 $\mathrm{m}^{3} /$ day occuring within the phyllites and the argillitic sediments. The highest and lowest average yield occurred within the the granites $\left(83 \mathrm{~m}^{3} /\right.$ day $)$ and sandstones $\left(29 \mathrm{~m}^{3} /\right.$ day) respectively. A plot of aquifer thickness verses yield and drawdown (Fig. 5) showed no direct relationship which means thick saturated zones does not necessarily increase the yield and drawdown of the borehole.

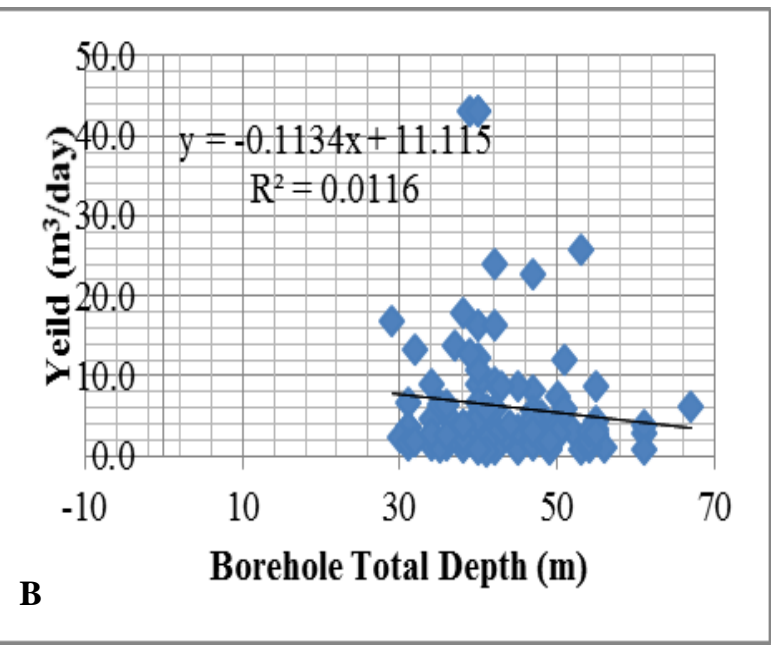

Fig. 4 Comparison of Borehole Total Depth with (A) Static Water Level and (B) Yield 

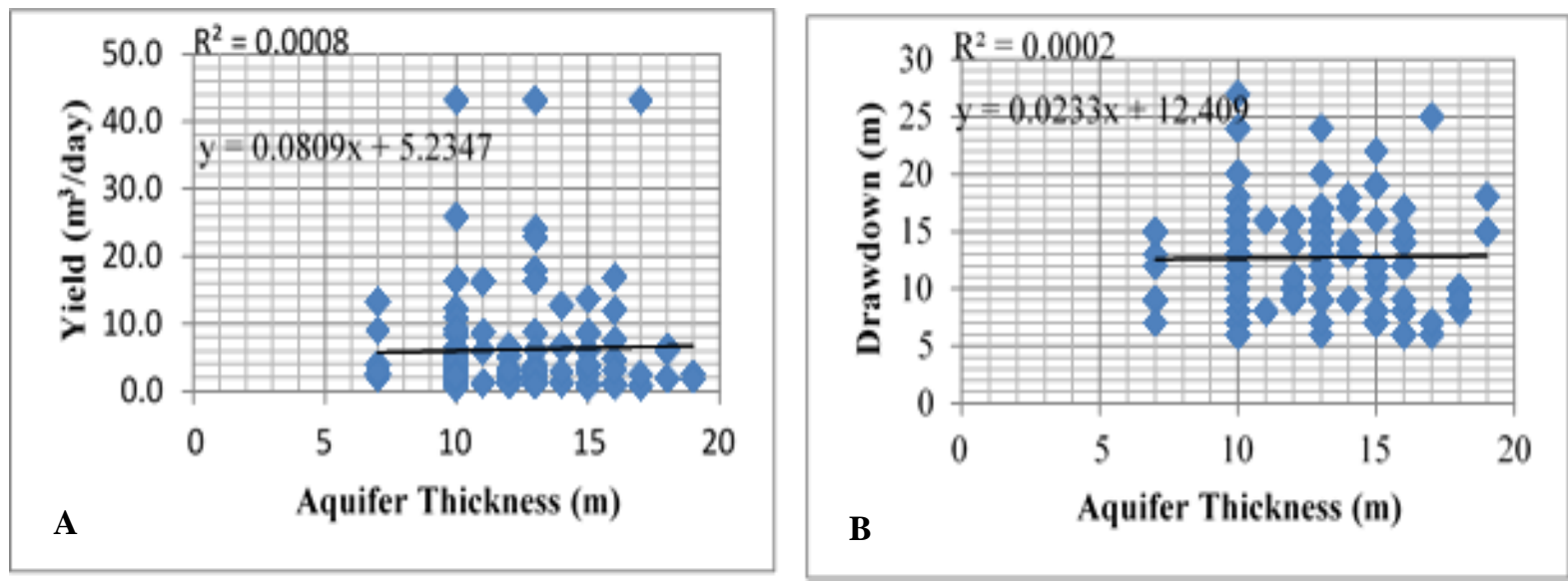

Fig. 5 Comparison of Aquifer Thickness with (A) Yield and (B) Drawdown

The average transmissivity was $5.12 \mathrm{~m}^{2} /$ day ranging from 0.3 to $43.7 \mathrm{~m}^{2} /$ day. The box-andwhisker plot (Tukey, 1977) of the transmissivity showed a normal distribution truncated at the left with the highest transmissivity occurring in the phyllites followed by the argillitic sediments, granites and sandstone (Fig. 6). The high permeability of the phyllites and argillitic sediments could be as a result of secondary porosity developed into fractures by the cleavage or

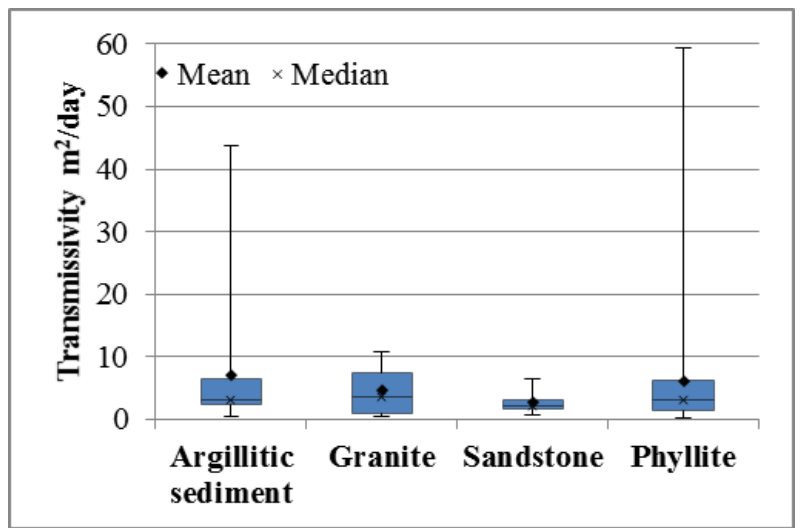

Fig. 6 Box and Whisker Plot of Transmissivity foliation planes. The average hydraulic conductivity was $0.42 \mathrm{~m} /$ day ranging from 0.02 to $4.56 \mathrm{~m} /$ day. From the frequency distribution of hydraulic conductivity in Fig. 7, three hydrogeological regimes could be inferred. The first group having hydraulic conductivity greater than $0.9 \mathrm{~m} /$ day, the second and third group having hydraulic conductivities between $0.9-0.09$ and less than $0.09 \mathrm{~m} /$ day respectively.

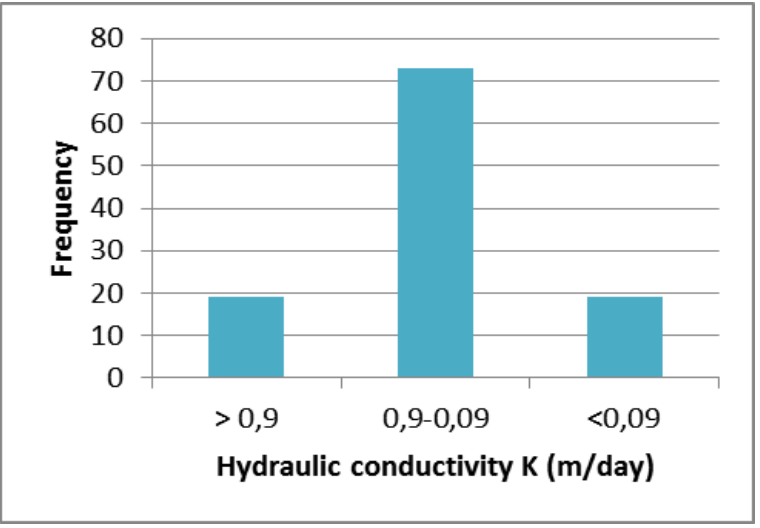

Fig. 7 Frequency Distribution of $\mathbf{K}$

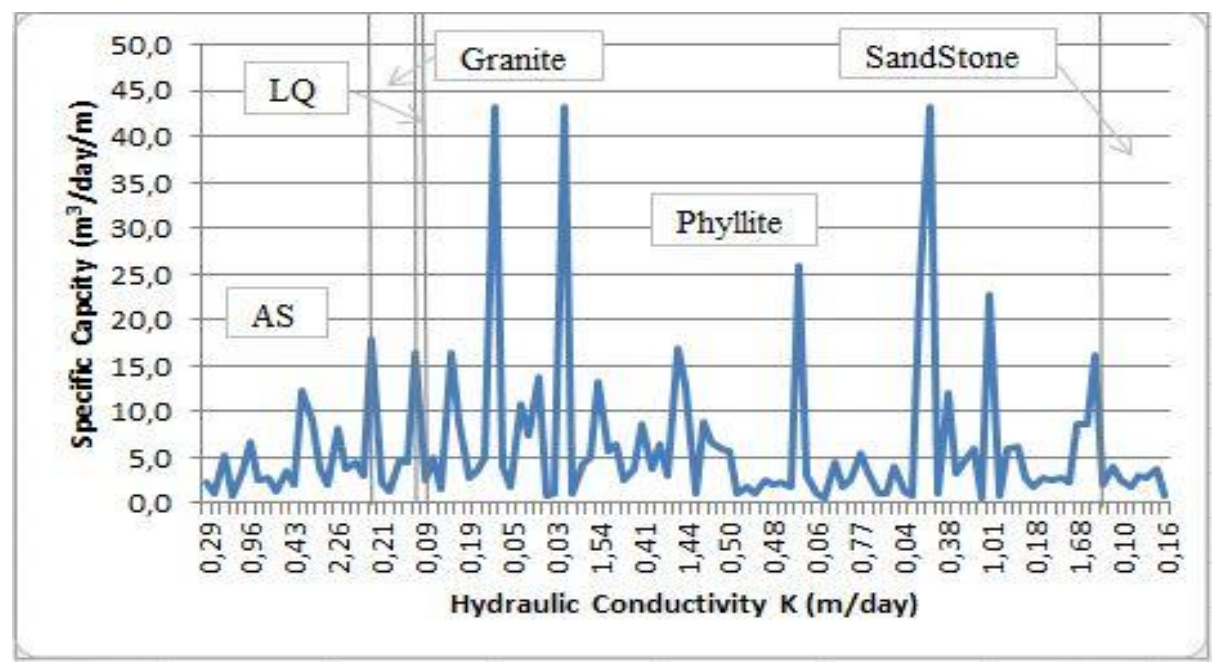

Fig. 8 Hydraulic Conductivity verses Specific Capacity 
According to Hölting and Coldewey (2009), the first group could be classified as aquifers having very high permeability and very good water bearing capacity (Table 1).

The second and third group could constitute aquifers with low to very low permeability with medium to small water bearing capacities. A total of $17 \%$ of boreholes belong to the first group whilst $66 \%$ and $17 \%$ belong to the second and third group respectively.

A plot of the hydraulic conductivity versus the specific capacity for the five main rock types in the study areas (Fig. 8) show an increasing specific capacity with increasing hydraulic conductivity. This plot suggests that, only rock types with hydraulic conductivity greater than $0.9 \mathrm{~m} /$ day would yield sustainable groundwater supply.

Fig. 9 shows the spatial distribution of maximum drawdown and aquifer weathering activity. The red colour indicates fresh aquifer rock whilst the yellow colour indicates aquifers with high degree of weathered rocks. The purple circle indicates the maximum drawdown in the area by the size of the circle. Generally, it is observed that those boreholes with higher hydraulic conductivity $(>0.9 \mathrm{~m} /$ day) show higher borehole drawdowns whereas lower hydraulic conductivity $(<0.01 \mathrm{~m} /$ day $)$, shows lower borehole drawdown (Fig.10). The fresh but jointed aquifer showed higher borehole drawdown values in areas where the hydraulic conductivity was greater than $0.9 \mathrm{~m} /$ day. This suggests that the area is characterised by both highly weathered and fresh rock aquifers. The highly weathered rocks are the so called regolith aquifers whilst the fresh rock types are the jointed and fractured aquifers. These joints and fractures serve as conduits for underground water storage. In areas with lower hydraulic conductivity they have very high drawdown and in some areas serve as aquitards.

The hydraulic conductivity distribution in the Adansi area trends in a South-West to North-East direction. The spatial distribution of the hydraulic conductivity and the geological structures show areas associated with high fractures in red and areas with no fractures in white (Fig. 10). Highly fractured areas are associated with higher hydraulic conductivity and vice versa. The red areas coincided with borehole points with hydraulic conductivity greater the $0.9 \mathrm{~m} /$ day whilst the white areas coincided with those with hydraulic conductivity less than $0.01 \mathrm{~m} /$ day. These trend suggest that the hydraulic conductivity is structurally controlled which confirm earlier work carried out in the region by Eisenlohr and Hirdes (Eisenlohr, 1989; Eisenlohr and Hirdes, 1992).

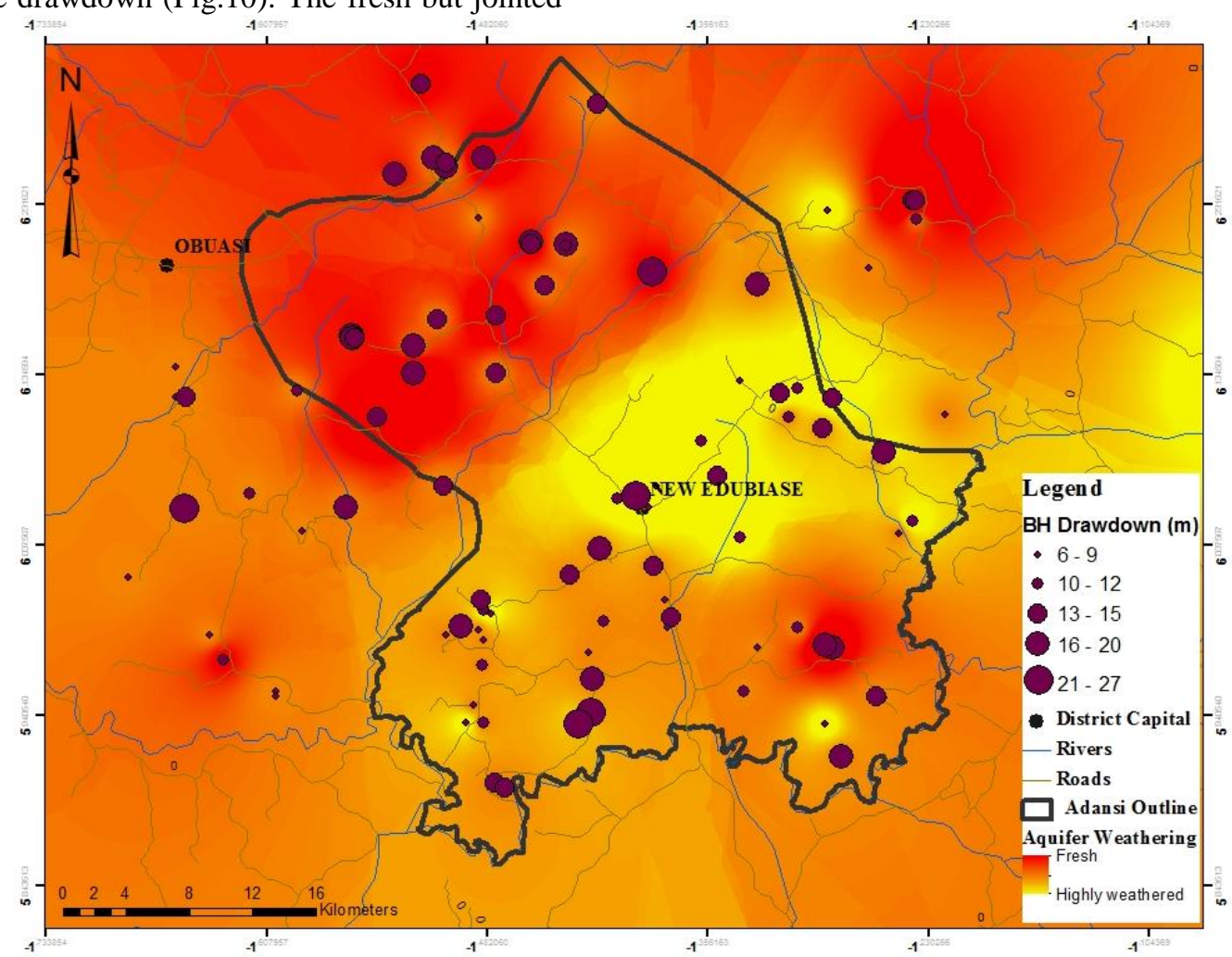

Fig. 9 Spatial Distribution of Drawdown and Aquifer Weathering Activity 


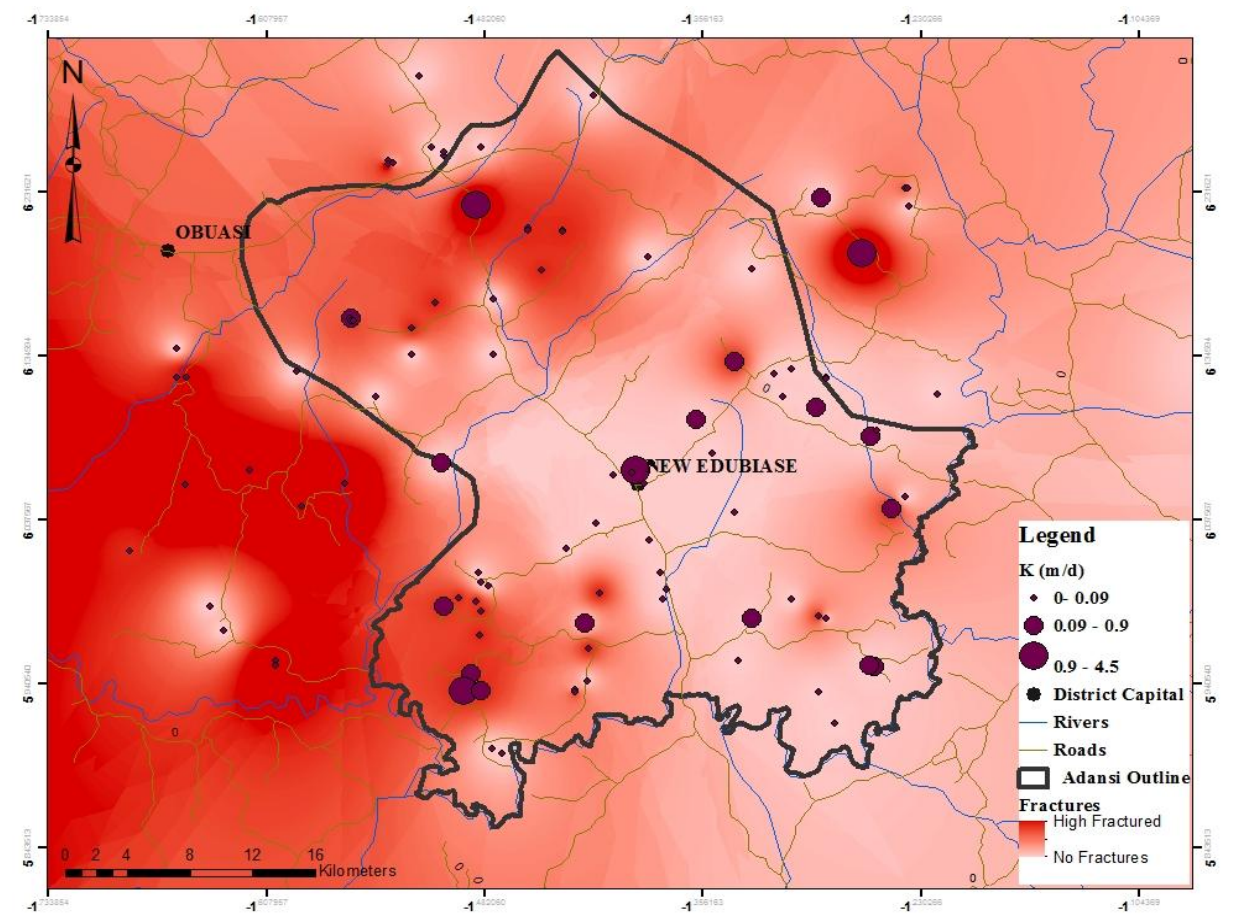

Fig. 10 Spatial Distribution of Hydraulic Conductivity and Geological Structures

Fig. 11 shows the spatial distribution of the specific capacity and the geological formations. The brown circle indicates the specific capacity by its size. Generally high specific capacities are associated with both the Tarkwaian and the Birimian metasedimentary rocks. Low specific capacities occur in all the four major formations of granitoids, Tarkwaian and the Birimain. The specific capacities are influenced by the hydraulic conductivity (Fig. 8).

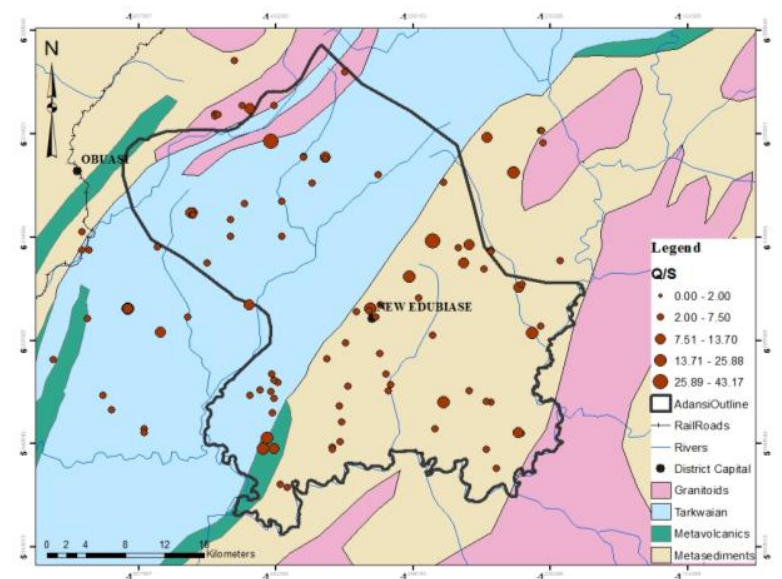

Fig.11Spatial Distribution of Specific Capacity and Geological Formations

\section{Conclusions}

The rock types in the Adansi area influences its hydraulic properties. The spatial distribution of these properties indicate that they are structurally controlled generally in the north-east, south-west direction forming the regolith and or fractured aquifers. The phyllite aquifer with hydraulic conductivity greater than $0.9 \mathrm{~m} /$ day and high transmissivity with good groundwater potential dominated the study area, followed by the argillitic sediments, sandstone, granites and quartz vein.

There is an increase in the total borehole depth with an increase in the static water level and decrease in the average yield. There is however no strong correlation between aquifer saturated thickness, yield and drawdown.

Three hydrogeological regimes were realised based on the hydraulic conductivity; greater than 0.9 $\mathrm{m} /$ day, between $0.9-0.09$ and less than $0.09 \mathrm{~m} /$ day respectively. Hydraulic conductivity increases with specific capacity in all rock types.

\section{References}

Anon. (2009), “ArcGIS Desktop 9.3 Help, Implementing Inverse Distance Weighted (IDW)", www.esri.com. Accessed: August 10, 2011.

Cooper, H. and Jacob, C. (1946), "A generalized graphical method for evaluating formation constants and summarizing well field history". Transactions of the American Geophysical Union 22, pp. 526-534.

Eisenlohr, B. (1989), “The structural geology of Birimian and Tarkwaian rocks of southwest Ghana", Unpublished, Rep. Arch. BGR, Hannover, 66 pp. 
Eisenlohr, B. and Hirdes, W. (1992). "The structural development of the early Proterozoic Birimian and Tarkwaian rocks in Southwest Ghana, West Africa", Africa Earth Science, 14 (3), pp. 313-325

Freeze, R. and Cherry, J. (1979), Groundwater. Englewood Cliffs, New Jersey, Prentice-Hall, $604 \mathrm{pp}$.

Halford, K. J. and Kuniansky, E. L. (2002), "Spreadsheet for Analysis of Aquifer-Test and Slug-Test Data", USGS Open File report 02197.

Hiscock, K. M. (2005), Hydrogeology Principles and Practice. Oxford, UK, Blackwell Publishing, 389 pp.

Hölting, B. and Coldewey, W. G. (2009), Hydrogeologie Einführung in die Allgemeine und Angewandte Hydrogeologie, Heidelberg, Spektrum Akademischer Verlag, 384 pp.

Kesse, G. O. (1985), The Mineral and Rock Resources of Ghana, A. A. Balkema Publishers, Rotterdam, 610 pp.

Knödel, K., Lange, G., Voigt, H.J. (2007), Environmental Geology: Handbook of Field Methods and Case Studies, Springer-Verlag Berlin Heidelberg, 1357 pp.

Martin, N. and van de Giesen, N. (2005). "Spatial Distribution of Groundwater Production and Development Potential in the Volta River basin of Ghana and Burkina Faso", Water International 30, No 2 , pp. 239-249.

Oldcorn, R., Bray, C., Roberts, L. and Bourassa, Y. (2013), "Technical Report on Mineral Resources and Mineral Reserves Golden Star Resources LTD, Wassa Gold Mine, Ghana”, NI 43-101, SRK Consulting Limited, 120 pp.

Perrouty S., Allières L., Jessell M.W., Baratoux L., Bourassa Y. and Crawford B. (2012), "Revised Eburnean geodynamic evolution of the goldrich southern Ashanti Belt, Ghana, with new field and geophysical evidence of preTarkwaian deformations", Precambrian Research, 204-205, pp. 12-39.

Theis, C. (1935), "The relationship between the lowering of the piezometric surface and the rate and duration of discharge of a well using groundwater storage", Transactions of the American Geophysical Union, 16, pp. 519-524.

Tukey, J. W. (1977). Exploratory Data Analysis. Reading, MA, Addisson-Wesley Publishing Company, 254pp.

\section{Authors}

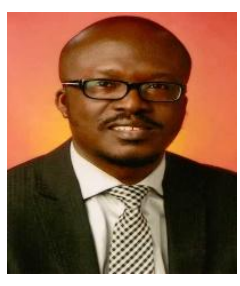

Dr Asare Asante-Annor is a lecturer at the Geological Engineering Department of the University of Mines and Technology, Tarkwa. He holds a BSc (Hons) in Geological Engineering from the Kwame Nkrumah University of Science and Technology, Kumasi, Ghana, an MSc in Environmental Resources Management and a $\mathrm{PhD}$ in
Environmental Engineering from Brandenburg Technical University, Germany. His areas of research include EIA, EMS, groundwater studies. $\mathrm{He}$ is a member of the International Association of Hydrogeologists.

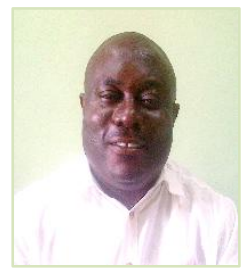

A. Ewusi holds a $\mathrm{PhD}$ Groundwater Geophysics, MSc. Environmental Resource Management from the Brandenburg University of Technology, Germany and a BSc. Geological Engineering from the Kwame Nkrumah University of Science and Technology, Kumasi, Ghana. He has postqualification experiences in Groundwater Exploration and Environmental Management in Germany, UK, Sierra Leone and Ghana. He is currently a Lecturer in Geophysics and Hydrogeology at the University of Mines and Technology (UMaT). 